\title{
Pengenalan ASL Menggunakan Metode Ekstraksi HOG Dan Klasifikasi Random Forest
}

\author{
Ningrum Larasati ${ }^{1}$, Siska Devella*2 ${ }^{2}$, Muhammad Ezar Al Rivan ${ }^{3}$ \\ ${ }^{1,2}$ STMIK Global Informatika MDP;Jl. Rajawali No.4, +62(711)376400/376360 \\ ${ }^{3}$ Program Studi Teknik Informatika, STMIK GI MDP, Palembang \\ e-mail: ${ }^{1}$ ningrumlarasati@mhs.mdp.ac.id, ${ }^{2}$ siskadevella@mdp.ac.id, ${ }^{3}$ meedzhar@mdp.ac.id
}

\begin{abstract}
Abstrak
Bahasa isyarat memiliki banyak jenis salah satunya yaitu American Sign Language (ASL). Pada Penelitian ini digunakan citra handshape alfabet ASL yang diekstraksi menggunakan fitur Histogram of Oriented Gradient (HOG) selanjutnya fitur yang dihasilkan digunakan untuk klasifikasi Random Forest. Hasil pengujian menunjukan bahwa dengan menggunakan fitur HOG dan metode klasifikasi Random Forest untuk pengenalan ASL memberikan tingkat accuracy yang baik, dengan nilai accuracy overall sebesar $99.10 \%$, nilai rata - rata accuracy per class $77.43 \%$, nilai rata - rata precission $88.81 \%$, dan nilai rata - rata recall $88.65 \%$.
\end{abstract}

Kata kunci-Bahasa Isyarat, American Sign Language (ASL), HOG, Random Forest

\section{Abstract}

Sign languages have many types, one of them is the American Sign Language (ASL). This study uses the ASL alphabet handshape image extracted with the Histogram of Oriented Gradient (HOG) feature and the resulting feature is used for the Random Forest classification. The test results show that using the HOG feature and the Random Forest classification method for ASL recognition gives a good accuracy rate, with an overall accuracy value of $99.10 \%$, an average accuracy value per class of $77.43 \%$, an average value of precision $88.81 \%$, and an average recall value of $88.65 \%$.

Keywords - Sign Language, American Sign Language (ASL), HOG, Random Forest

\section{PENDAHULUAN}

$\mathrm{P}$ ada hakikatnya manusia merupakan makhluk sosial yang saling membutuhkan dan saling berinteraksi. Dalam kehidupan sehari-hari manusia sebagai makhluk sosial dituntut untuk saling berinteraksi baik secara kelompok maupun secara individu. Manusia dapat berinteraksi salah satunya dengan cara berkomunikasi. Menurut Kamus Besar Bahasa Indonesia (KBBI), komunikasi merupakan proses pengiriman atau penerimaan pesan maupun berita dua arah antara dua orang atau lebih. Dengan adanya komunikasi manusia dapat saling memahami maksud dan tujuan dari apa yang akan disampaikan baik dengan maksud untuk kepentingan pribadi maupun untuk kepentingan kelompok.

Terdapat dua jenis komunikasi diantaranya komunikasi verbal dan komunikasi nonverbal [1]. Komunikasi verbal adalah komunikasi yang proses penyampaiannya secara verbal yang diwujudkan dengan bahasa lisan berbeda dengan komunikasi verbal yang melalui lisan, komunikasi nonverbal merupakan komunikasi yang pesannya 
disampaikan melalui bahasa isyarat [2]. Komunikasi nonverbal sendiri lebih banyak digunakan oleh mayarakat tuna rungu dan tuna wicara dikarenakan keterbatasan yang mereka miliki. Oleh sebab itu, bahasa isyarat menjadi kemampuan khusus yang dimiliki oleh tuna rungu dan tuna wicara.

Masyarakat umum lebih banyak menggunakan komunikasi secara lisan untuk berkomunikasi untuk menyampaikan pemikiran, pesan, dan perasaan. Dalam berkomunikasi masyarakat umum dapat berkomunikasi dengan bahasa lisan maupun tulisan namun masyarakat umum lebih sering menggunakan bahasa lisan daripada bahasa tulisan untuk menyampaikan pemikiran, pesan dan perasaan yang ingin disampaikan kepada orang lain.

Tuna rungu dan tuna wicara menggunakan bahasa isyarat sebagai salah satu cara mereka untuk berkomunikasi sehingga secara tidak langsung bahasa ini menjadi kemampuan khusus yang harus dikuasai oleh para tuna rungu maupun tuna wicara, namun bagi masyarakat umum bahasa isyarat merupakan bahasa yang jarang mereka gunakan. Masyarakat umum masih tidak memahami penggunaan bahasa isyarat khususnya fingerspelling alfabet dengan alasan yang berbeda - beda. Dengan keterbatasan pengetahuan masyarakat mengenai penggunaan bahasa isyarat dapat mengakibatkan kesulitan berkomunikasi antara masyarakat umum dengan tuna rungu dan tuna wicara [3]

Masalah tersebut dapat diatasi dengan suatu sistem yang mampu mengenali huruf alpabet dalam bahasa isyarat untuk membantu masyarakat umum dalam mengenali fingerspelling alfabet bahasa isyarat. Bahasa isyarat sendiri memiliki berbagai jenis salah satunya adalah American Sign Language (ASL). ASL adalah bahasa isyarat yang sering digunakan banyak orang di Amerika Utara baik tuna rungu maupun masyarakat umum. Bahasa isyarat ASL adalah bahasa yang dapat diekspresikan melalui gerakan tangan dan wajah (US Department of Health \& Human Services, 2019).

Menurut penelitian terdahulu yang telah dilakukan untuk pengenalan alpabet American Sign Language (ASL) menggunakan metode Histogram of Oriented Gradient (HOG) sebagai ekstraksi serta menggunakan k-Nearest Neighbors(k-NN) sebagai metode klasifikasi, pada penelitian ini menunjukan bahwa fitur ektraksi HOG memperoleh nilai akurasi yang cukup baik [4].

Berdasarkan penelitian dengan judul Recognition Indian Sign Language Based on Histogram of Oriented Gradient yang dilakukan oleh Tavari dan Deorankar [5] dapat disimpulkan dengan menggunakan metode $\mathrm{HOG}$ pada pengenalan Indian Sign Language sistem terbukti mampu mengenali 36 Indian Sign Language (alfabet dan numerik) dengan menggunakan fitur ekstraksi HOG dan penggunaan Artificial Neural Network (ANN) sebagai metode klasifikasi. Adapun berdasarkan penelitian yang dilakukan oleh Lahiani dan Neji [6] dengan menggunakan fitur gabungan antaara Histogram of Oriented Gradient (HOG) dengan Local Binary Pattern (LBP) pada Hand gesture recognition method based on $H O G-L B P$, penelitian ini dilakukan pada pengenalan hand gesture dengan menggunakan fitur ekstraksi HOG dan LBP dimana hasil yang didapatkan menunjukan penggunaan tingkat akurasi yang didapatkan menggunakan fitur HOG lebih besar dibandingkan dengan fitur ekstraksi LBP .

Adapun penelitian yang telah dilakukan oleh Zawbaa dkk [7] yang melakukan penelitian mengenai klasifikasi pada buah menggunakan algoritma Random Forest dan ekstraksi Scale - Invariant Feature Transform (SIFT) mendapatkan nilai akurasi baik. 
Pada penelitian yang dilakukan oleh Yohannes dkk [8] yaitu Penerapan Speeded-Up Robust Feature pada Random Forest Untuk Klasifikasi Motif Songket Palembang menghasilkan rata - rata akurasi sebesar $68.89 \%$. Penelitian yang dilakukan oleh Devella dkk [9] dengan menggunakan algoritma klasifikasi Random Forest menghasilkan akurasi sebesar $92.98 \%$.

Berdasarkan penelitian - penelitian terdahulu maka pada penelitian ini metode yang digunakan sebagai ekstraksi fitur yaitu HOG dan algoritma classifier yang digunakan adalah Random Forest.

\section{METODE PENELITIAN}

\subsection{Identifikasi Masalah}

Tahapan ini dilakukan identifikasi masalah penelitian yang berhubungan dengan citra bahasa isyarat, pengenalan pola fingerspelling American Sign Language (ASL) berdasarkan alfabet. Adapun alfabet yang digunakan terdiri dari 24 huruf tidak termasuk $\mathrm{J}$ dan $\mathrm{Z}$ merupakan huruf dinamis, karena kedua huruf ini membutuhkan pergerakan jari.

\subsection{Studi Literatur}

Melakukan tahapan pencarian jurnal yang berhubungan dengan pengenalan bahasa isyarat menggunakan berbagai macam metode yang akan digunakan diantaranya metode klasifikasi Random Forest dan ekstraksi menggunakan Histogram of Oriented Gradient (HOG).

\section{3 Pengumupulan Data}

Tahapan ini akan dilakukan pengumpulan data dimana data tersebut berjumlah 1680, data ini selanjuntya dibagi menjadi 2 kelompok data yaitu sebagai data training dan data testing. Data training sendiri terdiri dari 49 citra dan 21 citra sebagai data testing, yang terdiri dari 24 kelas ASL. Dataset yang digunakan tidak termasuk J dan Z karena bersifat dinamis. Citra yang digunakan sebagai data masing - masing memiliki resolusi 320x240 piksel. Dataset yang digunakan bersifat publik yang diperoleh dari https://github.com/mon95/Sign-Language-andStatic-gesture-recognition-using-sklearn.

\section{4 Perancangan Sistem}

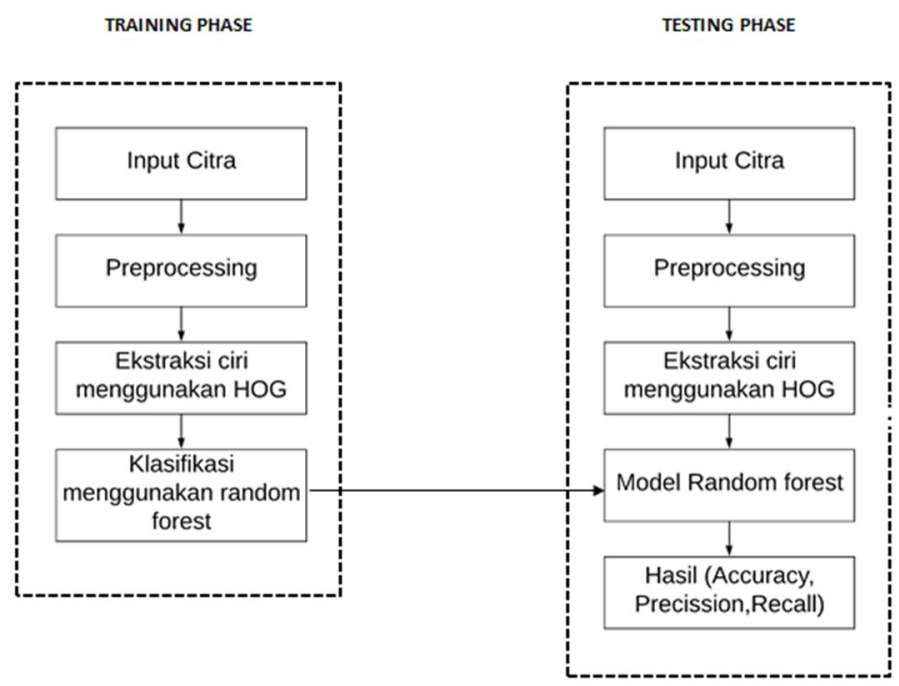

Gambar 1. Bagan Perancangan Sistem Pengenalan ASL 
Adapun tahapan dari perancangan sistem yang terbagi menjadi 2 diantaranya; Tahapan pertama yaitu training phase atau tahap latih, Pada tahap ini mula - mula citra awal yang berukuran 320x240 piksel dimasukan ke dalam tahap preprocessing dimana pada tahap preprosessing citra tersebut dipotong dan resize menjadi citra berukuran 91x91 piksel. Selanjutnya citra RGB tersebut diubah menjadi citra grayscale dan masuk ketahap ekstraksi ciri dengan menggunakan HOG. Dilanjutkan dengan proses klasifikasi dimana feature yang telah didapatkan dari ekstraksi HOG digunakan untuk menghasilkan model dengan menggunakan klasifikasi random forest.

Tahapan kedua yaitu testing phase atau tahap pengujian, citra awal yang berukuran $320 \times 240$ piksel dimasukan kedalam tahap preprocessing dimana pada tahap preprosessing citra tersebut dipotong dan resize menjadi citra berukuran $91 \times 91$ piksel. Selanjutnya citra RGB tersebut diubah menjadi citra grayscale dan masuk ketahap ekstraksi ciri dengan menggunakan HOG. Selanjutnya hasil yang diperoleh dari tahap testing akan dibandingkan dengan hasil model yang didapatkan dari klasifikasi pada tahap traning.

\section{5 Implementasi}

Setelah dilakukan proses perancangan, pada tahap selanjutnya dilakukan implementasi rancangan. Implementasi rancangan ini merupakan tindak lanjut dari rancangan yang telah dibuat sebelumnya yang diwujudkan ke dalam sebuah program MATLAB.

\section{6 Pengujian}

Pada tahap pengujian pada citra training dan citra testing untuk membedakan bahasa isyarat alfabet dan mengetahui seberapa besar tingkat keberhasilan akurasi yang didapatkan. Pengujian yang dilakukan menggunakan metode Random Forest untuk mengklasifikan data, dilanjutkan dengan mengevaluasi hasil akhir dari klasifikasi berupa accuracy, precission dan recall dengan menggunakan HOG. Dengan menggunakan rumus sebagai berikut :

Tabel 1. Confussion Matrix

\begin{tabular}{|c|c|c|c|}
\hline & \multicolumn{2}{|c|}{ True Values } \\
\hline & & True & False \\
\hline \multirow{2}{*}{ 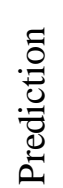 } & True & $\mathrm{TP}$ & FP \\
\hline & False & FN & $\mathrm{TN}$ \\
\hline
\end{tabular}

Accuracy $=\frac{\mathrm{TP}+\mathrm{TN}}{\mathrm{TP}+\mathrm{TN}+\mathrm{FP}+\mathrm{FN}} \times 100$

Precision $=\frac{T P}{T P+F P} \times 100$

Recall $=\frac{T P}{F N+T P} \times 100$

Keterangan:

TP : Jumlah data positif citra yang terklasifikasi dengan benar oleh sistem

TN : Jumlah data negatif citra yang terklasifikasi dengan benar oleh sistem

FP : Jumlah data positif citra yang terklasifikasi salah oleh sistem

FN : Jumlah data negatif citra yang terklasifikasi salah oleh sistem 


\section{HASIL DAN PEMBAHASAN}

\subsection{Implementasi Preprocessing}

Pada pengenalan ASL terdapat dua tahapan yang terdiri dari tahap latih dan tahap uji pada tahap latih dilakukan preprocessing terlebih dahulu dimana pada tahap ini citra berukuran 320x240 dipotong dan diubah ukurannya menjadi 90x90 kemudian di grayscale.
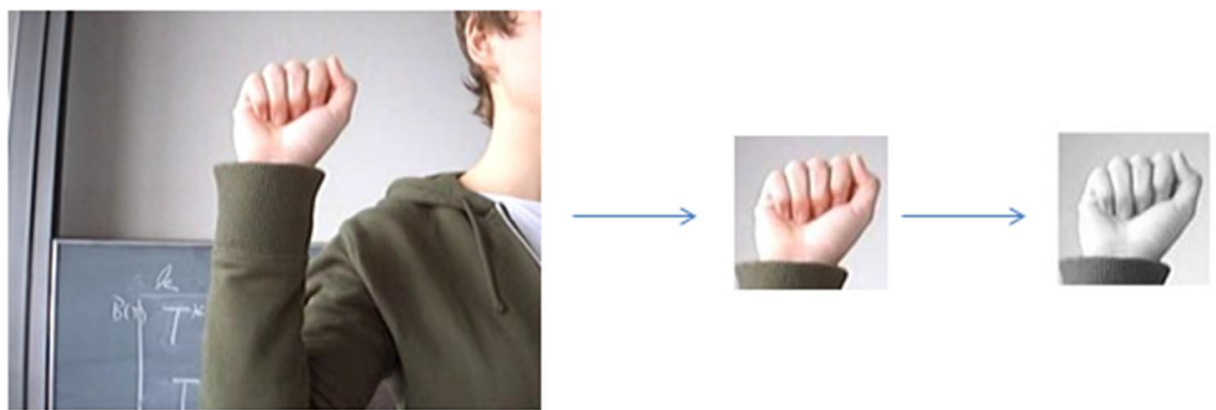

Gambar 2. Proses Tahap Preprocessing

\subsection{Implementasi $H O G$}

Dilakukan Proses Ekstraksi Ciri menggunakan Histogram of Oriented Gradient (HOG) pada ASL dari hasil tahap preprocessing hasil yang diperoleh jumlah cell [11 11] dan jumlah block [10 10], dengan ukuran cell [2 2] = 4 cell berisi 9 bin dengan ukuran block [10 10] = 100 block sehingga di peroleh panjang feature vector 3600, sehingga panjang feature vector yang diperoleh untuk data latih sebesar 1176x3600 dan untuk data uji sebesar 504x3600.

\subsection{Implementasi Random Forest}

Masuk ke tahap klasifikasi dengan menggunakan metode Random Forest, dimana hasil ektraksi dengan menggunakan HOG atau feature vector yang didapatkan dari hasil latih dengan menggunakan fitur ekstraksi HOG akan menghasilkan classifier berbentuk banyak pohon. pohon tersebut akan memilih class dengan tingkat kepopularan tertinggi. berdasarkan output ini yang akan menghasilkan hasil akhir klasifikasi berupa pohon.

\subsection{Pengujian}

Hasil dari klasifikasi dengan menggunakan random forest akan menghasilkan confussion matrix. Terbagi menadi 2 yaitu HOG tanpa LDA dan HOG dengan LDA, dimana pengujian dengan LDA memiliki 3 skenario yang pertama menggunakan ekstraksi HOG - LDA dengan reduce $10 \%$ dan klasifikasi random forest, skenario kedua menggunakan HOG dan LDA dengan reduce 20\%, skenario ketiga menggunakan ekstraksi HOG - LDA dengan reduce $33.33 \%$.

\subsubsection{Pengujian HOG tanpa LDA}

Pengujian menggunakan skenario pertama atau pengujian dengan menggunakan ekstraksi fitur HOG pada ASL memperoleh hasil berupa confussion matrix dengan nilai sebagai berikut: 
Tabel 2. Hasil Confussion Matrix HOG

Tanpa LDA

\begin{tabular}{|c|c|c|}
\hline No. & Alfabet & Diindentifikasi Benar \\
\hline 1. & A & 20 data \\
\hline 2. & B & 21 data \\
\hline 3. & C & 19 data \\
\hline 4. & D & 16 data \\
\hline 5. & E & 21 data \\
\hline 6. & F & 21 data \\
\hline 7. & G & 20 data \\
\hline 8. & H & 18 data \\
\hline 9. & I & 18 data \\
\hline 10. & K & 17 data \\
\hline 11. & L & 20 data \\
\hline 12. & M & 12 data \\
\hline 13. & N & 15 data \\
\hline 14. & O & 20 data \\
\hline 15. & P & 20 data \\
\hline 16. & Q & 21 data \\
\hline 17. & R & 16 data \\
\hline 18. & S & 20 data \\
\hline 19. & T & 18 data \\
\hline 20. & U & 19 data \\
\hline 21. & V & 17 data \\
\hline 22. & W & 19 data \\
\hline 23. & X & 19 data \\
\hline 24. & Y & 19 data \\
\hline & & \\
\hline
\end{tabular}

\subsubsection{Pengujian HOG dengan LDA Skenario Pertama}

Pengujian menggunakan skenario kedua atau pengujian dengan menggunakan ekstraksi fitur HOG dengan LDA reduce $10 \%$ pada ASL memperoleh hasil berupa confussion matrix dengan nilai sebagai berikut:

Tabel 3. Hasil Confussion Matrix HOG Dengan

LDA Reduce $10 \%$

\begin{tabular}{|c|c|c|}
\hline No. & Alfabet & Diidentifikasi Benar \\
\hline 1. & A & 19 data \\
\hline 2. & B & 18 data \\
\hline 3. & C & 18 data \\
\hline 4. & D & 7 data \\
\hline 5. & E & 2 data \\
\hline 6. & F & 20 data \\
\hline 7. & G & 8 data \\
\hline 8. & H & 6 data \\
\hline
\end{tabular}


Jatisi

ISSN 2407-4322

Vol. 8, No. 2, Juni 2021, Hal. 611-622

E- ISSN 2503-2933

617

\begin{tabular}{|c|c|c|}
\hline 9. & I & 10 data \\
\hline 10. & K & 14 data \\
\hline 11. & L & 21 data \\
\hline 12. & M & data \\
\hline 13. & N & 3 data \\
\hline 14. & O & 10 data \\
\hline 15. & $\mathrm{P}$ & 20 data \\
\hline 16. & $\mathrm{Q}$ & 19 data \\
\hline 17. & $\mathrm{R}$ & 1 data \\
\hline 18. & $\mathrm{~S}$ & 4 data \\
\hline 19. & $\mathrm{~T}$ & 5 data \\
\hline 20. & $\mathrm{U}$ & 17 data \\
\hline 21. & $\mathrm{~V}$ & 8 data \\
\hline 22. & $\mathrm{~W}$ & 19 data \\
\hline 23. & $\mathrm{X}$ & 0 data \\
\hline 24. & $\mathrm{Y}$ & 14 data \\
\hline & & \\
\hline
\end{tabular}

\subsubsection{Pengujian HOG dengan LDA Skenario Kedua}

Pengujian menggunakan skenario ketiga atau pengujian dengan menggunakan ekstraksi fitur HOG dengan LDA reduce $20 \%$ pada ASL memperoleh hasil berupa confussion matrix dengan nilai seperti berikut:

Tabel 4. Hasil Confussion Matrix HOG Dengan

LDA Reduce $20 \%$

\begin{tabular}{|c|c|c|}
\hline No. & Alfabet & Diidentifkasi Benar \\
\hline 1. & A & 11 data \\
\hline 2. & B & 19 data \\
\hline 3. & C & 17 data \\
\hline 4. & D & 0 data \\
\hline 5. & E & 3 data \\
\hline 6. & F & 20 data \\
\hline 7. & G & 1 data \\
\hline 8. & H & 10 data \\
\hline 9. & I & 5 data \\
\hline 10. & K & 18 data \\
\hline 11. & L & 17 data \\
\hline 12. & M & 1 data \\
\hline 13. & N & 1 data \\
\hline 14. & O & 6 data \\
\hline 15. & P & 20 data \\
\hline 16. & Q & 20 data \\
\hline 17. & R & 0 data \\
\hline 18. & S & 2 data \\
\hline 19. & T & 2 data \\
\hline
\end{tabular}




\begin{tabular}{|c|c|c|}
\hline 20. & $\mathrm{U}$ & 6 data \\
\hline 21. & $\mathrm{~V}$ & 1 data \\
\hline 22. & $\mathrm{~W}$ & 21 data \\
\hline 23. & $\mathrm{X}$ & 0 data \\
\hline 24. & $\mathrm{Y}$ & 13 data \\
\hline
\end{tabular}

\subsubsection{Pengujian HOG Dengan LDA Skenario Ketiga}

Pengujian menggunakan skenario keempat atau pengujian dengan menggunakan ekstraksi fitur HOG dengan LDA reduce $33.33 \%$ pada ASL memperoleh hasil berupa confussion matrix dengan nilai seperti berikut:

Tabel 5. Hasil Confussion Matrix HOG Dengan LDA Reduce $33.33 \%$

\begin{tabular}{|c|c|c|}
\hline No. & Alfabet & Diidentifikasi Benar \\
\hline 1. & A & 13 data \\
\hline 2. & B & 15 data \\
\hline 3. & C & 16 data \\
\hline 4. & D & 6 data \\
\hline 5. & E & 7 data \\
\hline 6. & F & 20 data \\
\hline 7. & G & 1 data \\
\hline 8. & H & 5 data \\
\hline 9. & I & 9 data \\
\hline 10. & K & 13 data \\
\hline 11. & L & 21 data \\
\hline 12. & M & 3 data \\
\hline 13. & N & 1 data \\
\hline 14. & O & 3 data \\
\hline 15. & P & 21 data \\
\hline 16. & Q & 18 data \\
\hline 17. & R & 2 data \\
\hline 18. & S & 3 data \\
\hline 19. & T & 4 data \\
\hline 20. & U & 4 data \\
\hline 21. & V & 0 data \\
\hline 22. & W & 20 data \\
\hline 23. & X & 0 data \\
\hline 24. & Y & 15 data \\
\hline & & \\
\hline
\end{tabular}

\subsection{Hasil Pengujian}

Hasil uji didapatkan berdasarkan confussion matrix yang diperoleh menggunakan metode Random Forest. Selanjutnya hasil uji tersebut diolah untuk memperoleh nilai accuracy overall, accuracy per class, precission, dan recall. 


\subsubsection{Hasil Pengujian HOG Tanpa LDA}

Pada pengujian pengenalan ASL dengan menggunakan fitur ekstraksi HOG pada traning, testing dan Random Forest sebagai classifier. berdasarkan pengujian yang telah dilakukan maka didapatkan nilai accuracy overall sebesar $99.10 \%$ hasil ini didapatkan menggunakan Persamaan 1. Adapun nilai dari accuracy, Precission dan recall dari masing masing kelas yang diperoleh dapat dilihat pada Tabel 5 sebagai berikut.

Tabel 6. Accuracy, Precission, dan Recall HOG Tanpa LDA

\begin{tabular}{|l|l|l|l|l|l|l|l|l|}
\hline Alfabet & Class & TP & TN & FP & FN & Accuracy (\%) & Precission (\%) & Recall (\%) \\
\hline A & 1 & 20 & 480 & 3 & 1 & 99.21 & 86.96 & 95.24 \\
\hline B & 2 & 21 & 482 & 1 & 0 & 99.81 & 95.45 & 100 \\
\hline C & 3 & 19 & 482 & 1 & 2 & 99.41 & 95.00 & 90.48 \\
\hline D & 4 & 16 & 483 & 0 & 4 & 99.21 & 100 & 80.00 \\
\hline E & 5 & 21 & 480 & 4 & 0 & 99.21 & 84.00 & 100 \\
\hline F & 6 & 21 & 482 & 1 & 0 & 99.81 & 95.45 & 100 \\
\hline G & 7 & 20 & 480 & 3 & 1 & 99.21 & 86.96 & 95.24 \\
\hline H & 8 & 18 & 484 & 3 & 3 & 98.82 & 85.71 & 85.71 \\
\hline I & 9 & 18 & 485 & 1 & 3 & 99.22 & 94.74 & 85.71 \\
\hline K & 10 & 17 & 480 & 3 & 4 & 98.62 & 85.00 & 80.95 \\
\hline L & 11 & 20 & 482 & 2 & 1 & 99.41 & 90.91 & 95.24 \\
\hline M & 12 & 12 & 481 & 5 & 9 & 97.24 & 70.59 & 57.14 \\
\hline N & 13 & 15 & 488 & 5 & 6 & 97.86 & 75.00 & 71.43 \\
\hline O & 14 & 20 & 483 & 3 & 1 & 99.22 & 86.96 & 95.24 \\
\hline P & 15 & 20 & 484 & 1 & 1 & 99.61 & 95.24 & 95.24 \\
\hline Q & 16 & 21 & 481 & 2 & 0 & 99.61 & 91.30 & 100 \\
\hline R & 17 & 16 & 485 & 3 & 5 & 98.43 & 84.21 & 76.19 \\
\hline S & 18 & 20 & 484 & 4 & 1 & 99.02 & 83.33 & 95.24 \\
\hline T & 19 & 18 & 485 & 0 & 3 & 99.41 & 100 & 85.71 \\
\hline U & 20 & 19 & 484 & 3 & 2 & 99.02 & 86.36 & 90.48 \\
\hline V & 21 & 17 & 483 & 1 & 4 & 99.01 & 94.44 & 80.95 \\
\hline W & 22 & 19 & 485 & 4 & 2 & 98.83 & 82.61 & 90.48 \\
\hline X & 23 & 19 & 485 & 3 & 2 & 99.02 & 86.36 & 90.48 \\
\hline Y & 24 & 19 & 485 & 1 & 2 & 99.41 & 95.00 & 90.48 \\
\hline
\end{tabular}

\subsubsection{Hasil Pengujian HOG Dengan LDA Skenario Pertama}

Pada pengujian pengenalan ASL dengan menggunakan fitur ekstraksi HOG dengan LDA reduce $10 \%$ pada traning, testing dan Random Forest sebagai classifier. berdasarkan pengujian yang telah dilakukan maka didapatkan nilai accuracy overall sebesar $96.21 \%$ hasil ini didapatkan menggunakan Persamaan 1. Adapun nilai dari accuracy, Precission dan recall dari masing - masing kelas yang diperoleh dapat dilihat pada Tabel 6 sebagai berikut.

Tabel 7. Accuracy, Precission, dan Recall HOG Dengan LDA Reduce 10\%

\begin{tabular}{|c|c|c|c|c|c|c|c|c|}
\hline Alfabet & Class & TP & TN & FP & FN & Accuracy (\%) & Precission (\%) & Recall (\%) \\
\hline A & 1 & 19 & 482 & 1 & 2 & 99.40 & 95.00 & 90.48 \\
\hline B & 2 & 18 & 473 & 11 & 3 & 97.23 & 62.07 & 85.71 \\
\hline C & 3 & 18 & 480 & 3 & 3 & 98.81 & 85.71 & 85.71 \\
\hline D & 4 & 7 & 481 & 2 & 14 & 96.83 & 77.78 & 33.33 \\
\hline E & 5 & 2 & 486 & 0 & 16 & 96.83 & 100 & 11.11 \\
\hline F & 6 & 20 & 479 & 4 & 1 & 99.01 & 83.33 & 95.24 \\
\hline G & 7 & 8 & 481 & 2 & 13 & 97.02 & 80.00 & 38.10 \\
\hline H & 8 & 6 & 484 & 2 & 15 & 96.65 & 75.00 & 28.57 \\
\hline I & 9 & 10 & 483 & 4 & 11 & 97.05 & 71.43 & 47.62 \\
\hline
\end{tabular}




\begin{tabular}{|c|c|c|c|c|c|c|c|c|}
\hline $\mathrm{K}$ & 10 & 14 & 465 & 18 & 7 & 95.04 & 43.75 & 66.67 \\
\hline $\mathrm{L}$ & 11 & 21 & 466 & 28 & 0 & 94.56 & 42.86 & 100 \\
\hline $\mathrm{M}$ & 12 & 4 & 488 & 2 & 17 & 96.28 & 66.67 & 19.05 \\
\hline $\mathrm{N}$ & 13 & 3 & 489 & 0 & 18 & 96.47 & 100 & 14.29 \\
\hline $\mathrm{O}$ & 14 & 10 & 491 & 1 & 11 & 97.66 & 90.91 & 47.62 \\
\hline $\mathrm{P}$ & 15 & 20 & 462 & 43 & 1 & 91.63 & 31.75 & 95.24 \\
\hline $\mathrm{Q}$ & 16 & 19 & 475 & 0 & 2 & 99.60 & 100 & 90.48 \\
\hline $\mathrm{R}$ & 17 & 1 & 490 & 21 & 20 & 92.29 & 4.545 & 4.762 \\
\hline $\mathrm{S}$ & 18 & 4 & 494 & 10 & 17 & 94.86 & 28.57 & 19.05 \\
\hline $\mathrm{T}$ & 19 & 5 & 499 & 1 & 16 & 96.74 & 83.33 & 23.81 \\
\hline $\mathrm{U}$ & 20 & 17 & 480 & 35 & 4 & 92.72 & 32.69 & 80.95 \\
\hline $\mathrm{V}$ & 21 & 8 & 486 & 1 & 13 & 97.24 & 88.89 & 38.10 \\
\hline $\mathrm{W}$ & 22 & 19 & 484 & 44 & 2 & 91.62 & 30.16 & 90.48 \\
\hline $\mathrm{X}$ & 23 & 0 & 504 & 0 & 21 & 96.00 & 0 & 0 \\
\hline $\mathrm{Y}$ & 24 & 14 & 490 & 0 & 7 & 98.63 & 100 & 66.67 \\
\hline
\end{tabular}

\subsubsection{Hasil Pengujian HOG Dengan LDA Skenario Kedua}

Pada pengujian pengenalan ASL dengan menggunakan fitur ekstraksi HOG dengan LDA reduce $20 \%$ pada traning, testing dan Random Forest sebagai classifier. berdasarkan pengujian yang telah dilakukan maka didapatkan nilai accuracy overall sebesar $95.14 \%$ hasil ini didapatkan menggunakan Persamaan 1. Adapun nilai dari accuracy, Precission dan recall dari masing - masing kelas yang diperoleh dapat dilihat pada Tabel 7 sebagai berikut.

Tabel 8. Accuracy, Precission, dan Recall HOG Dengan LDA Reduce 20\%

\begin{tabular}{|l|l|l|l|l|l|l|l|l|}
\hline Alfabet & Class & TP & TN & FP & FN & Accuracy $(\%)$ & Precission $(\%)$ & Recall $(\%)$ \\
\hline A & 1 & 11 & 481 & 2 & 10 & 97.62 & 84.62 & 52.38 \\
\hline B & 2 & 19 & 482 & 2 & 2 & 99.21 & 90.48 & 90.48 \\
\hline C & 3 & 17 & 478 & 5 & 4 & 98.21 & 77.27 & 80.95 \\
\hline D & 4 & 0 & 483 & 0 & 21 & 95.83 & 0 & 0 \\
\hline E & 5 & 3 & 483 & 8 & 18 & 94.92 & 27.27 & 14.29 \\
\hline F & 6 & 20 & 475 & 0 & 1 & 99.80 & 100 & 95.24 \\
\hline G & 7 & 1 & 486 & 4 & 20 & 95.3 & 20 & 4.762 \\
\hline H & 8 & 10 & 483 & 2 & 11 & 97.43 & 83.33 & 47.62 \\
\hline I & 9 & 5 & 482 & 137 & 16 & 76.09 & 3.521 & 23.81 \\
\hline K & 10 & 18 & 395 & 24 & 3 & 93.86 & 42.86 & 85.71 \\
\hline L & 11 & 17 & 477 & 17 & 4 & 95.92 & 50 & 80.95 \\
\hline M & 12 & 1 & 497 & 0 & 20 & 96.14 & 100 & 4.762 \\
\hline N & 13 & 1 & 498 & 3 & 20 & 95.59 & 25 & 4.762 \\
\hline O & 14 & 6 & 492 & 0 & 15 & 97.08 & 100 & 28.57 \\
\hline P & 15 & 20 & 479 & 13 & 1 & 97.27 & 60.61 & 95.24 \\
\hline Q & 16 & 20 & 477 & 24 & 1 & 95.21 & 45.45 & 95.24 \\
\hline R & 17 & 0 & 495 & 0 & 21 & 95.93 & 0 & 0 \\
\hline S & 18 & 2 & 495 & 1 & 19 & 96.13 & 66.67 & 9.524 \\
\hline T & 19 & 2 & 502 & 1 & 19 & 96.18 & 66.67 & 9.524 \\
\hline U & 20 & 6 & 488 & 2 & 15 & 96.67 & 75 & 28.57 \\
\hline V & 21 & 1 & 486 & 0 & 20 & 96.06 & 100 & 4.762 \\
\hline W & 22 & 21 & 481 & 66 & 0 & 88.38 & 24.14 & 100 \\
\hline X & 23 & 0 & 504 & 0 & 21 & 96 & 0 & 0 \\
\hline Y & 24 & 13 & 491 & 2 & 8 & 98.05 & 86.67 & 61.90 \\
\hline
\end{tabular}




\subsubsection{Hasil Pengujian HOG Dengan LDA Skenario Ketiga}

Pada pengujian pengenalan ASL dengan menggunakan fitur ekstraksi HOG dengan LDA reduce $33.33 \%$ pada traning, testing dan Random Forest sebagai classifier. berdasarkan pengujian yang telah dilakukan maka didapatkan nilai accuracy overall sebesar $95.44 \%$ hasil ini didapatkan menggunakan Persamaan 1. Adapun nilai dari accuracy, Precission dan recall dari masing - masing kelas yang diperoleh dapat dilihat pada Tabel 8 sebagai berikut.

Tabel 9. Accuracy, Precission, dan Recall HOG Dengan LDA Reduce 33.33\%

\begin{tabular}{|l|l|l|l|l|l|l|l|l|}
\hline Alfabet & Class & TP & TN & FP & FN & Accuracy (\%) & Precission $(\%)$ & Recall(\%) \\
\hline A & 1 & 13 & 481 & 2 & 8 & 98.02 & 86.67 & 61.90 \\
\hline B & 2 & 15 & 481 & 2 & 6 & 98.41 & 88.24 & 71.43 \\
\hline C & 3 & 16 & 474 & 9 & 5 & 97.22 & 64.00 & 76.19 \\
\hline D & 4 & 6 & 483 & 0 & 15 & 97.02 & 100 & 28.57 \\
\hline E & 5 & 7 & 483 & 0 & 14 & 97.22 & 100 & 33.33 \\
\hline F & 6 & 20 & 472 & 14 & 1 & 97.04 & 58.82 & 95.24 \\
\hline G & 7 & 1 & 483 & 0 & 20 & 96.03 & 100 & 4.762 \\
\hline H & 8 & 5 & 483 & 1 & 16 & 96.63 & 83.33 & 23.81 \\
\hline I & 9 & 9 & 486 & 0 & 12 & 97.63 & 100 & 42.86 \\
\hline K & 10 & 13 & 463 & 32 & 8 & 92.25 & 28.89 & 61.90 \\
\hline L & 11 & 21 & 419 & 87 & 0 & 83.49 & 19.44 & 100 \\
\hline M & 12 & 3 & 491 & 0 & 18 & 96.48 & 100 & 14.29 \\
\hline N & 13 & 1 & 498 & 1 & 20 & 95.96 & 50 & 4.762 \\
\hline O & 14 & 3 & 500 & 0 & 18 & 96.55 & 100 & 14.29 \\
\hline P & 15 & 21 & 463 & 67 & 0 & 88.27 & 23.86 & 100 \\
\hline Q & 16 & 18 & 483 & 3 & 3 & 98.84 & 85.71 & 85.71 \\
\hline R & 17 & 2 & 494 & 1 & 19 & 96.12 & 66.67 & 9.524 \\
\hline S & 18 & 3 & 496 & 0 & 18 & 96.52 & 100 & 14.29 \\
\hline T & 19 & 4 & 500 & 1 & 17 & 96.55 & 80.00 & 19.05 \\
\hline U & 20 & 4 & 492 & 7 & 17 & 95.38 & 36.36 & 19.05 \\
\hline V & 21 & 0 & 497 & 0 & 21 & 95.95 & 0 & 0 \\
\hline W & 22 & 20 & 482 & 54 & 1 & 90.13 & 27.03 & 95.24 \\
\hline X & 23 & 0 & 504 & 0 & 21 & 96.00 & 0 & 0 \\
\hline Y & 24 & 15 & 489 & 0 & 5 & 99.02 & 100 & 75 \\
\hline
\end{tabular}

\section{KESIMPULAN}

Berdasarakan penelitian yang telah dilakukan dapat disimpulkan dengan penggunaan fitur HOG dengan klasifikasi Random Forest mampu meningkatkan nilai akurasi pada pengenalan American Sign Language yang dilakukan sebelumnya oleh Kevin dan Arta dengan menggunakan fitur HOG - LDA dan klasifikasi KNN yang memperoleh hasil accuracy overall sebesar 72.43.\% dan dapat disimpulkan juga bahwa dengan menggunakan fitur HOG dan klasifikasi Random Forest dapat memperoleh hasil accuracy yang lebih baik dari pada menggunakan fitur HOG - LDA dan klasifikasi Random Forest, tingkat akurasi dengan menggunakan klasifikasi Random Forest dan fitur HOG tanpa LDA memperoleh hasil accuracy sebesar $99.10 \%$ sedangakan pada fitur HOG dengan LDA yang memperoleh nilai accuracy sebesar $96.21 \%$. 


\section{SARAN}

Berdasarkan penelitian yang telah dilakukan adapun saran dari penulis yang dapat dilakukan oleh peneliti selanjutnya diantara sebagai berikut:

1. Penelitian ini menggunakan dataset publik, belum diketahui hasil akurasi yang diperoleh jika dataset yang digunakan diambil secara langsung oleh peneliti.

2. Penelitian ini belum diketahui apakah dengan menggunakan banyak pohon atau sedikit pohon pada klasifikasi Random Forest mampu mempengaruhi nilai akurasi.

\section{DAFTAR PUSTAKA}

[1] J. A. DeVito. 2015, The Interpersonal Communication Book, Pearson.

[2] H. Maulana dan G. 2013, Gumelar, Psikologi Komunikasi dan Persuasi, Jakarta Akademia Permata, Jakarta.

[3] I. Fareza, R. Busdin, M. E. Al Rivan, dan H. Irsyad. 2018, "Pengenalan Alfabet Bahasa Isyarat Amerika Menggunakan Edge Oriented Histogram dan Image Matching," J. Tek. Inform. dan Sist. Inf., Vol. 4, No. 1, Hal. 82-92, doi: 10.28932/jutisi.v4i1.747.

[4] M. E. Al Rivan, H. Irsyad, K. Kevin, dan A. T. Narta. 2019, "Pengenalan Alfabet American Sign Language Menggunakan K-Nearest Neighbors Dengan Ekstraksi Fitur Histogram of Oriented Gradients," JuTISI, Vol. 5, No. 3, Hal. 328-339.

[5] N. V Tavari dan P. a V Deorankar, "Indian Sign Language Recognition Based on Histograms of Oriented Gradient,” Int. J. Comput. Sci. Inf. Technol., Vol. 5, No. 3, Hal. 3657-3660, 2014.

[6] H. Lahiani dan M. Neji. 2018, "Hand Gesture Recognition Method Based on HOG-LBP Features for Mobile Devices,” Procedia Comput. Sci., Vol. 126, Hal. 254-263, doi: 10.1016/j.procS.2018.07.259.

[7] H. M. Zawbaa, M. Hazman, M. Abbass, dan A. E. Hassanien, 2014 "Automatic Fruit Classification Using Random Forest Algorithm," 14th Int. Conf. Hybrid Intell. Syst. HIS Hal. 164-168, doi: 10.1109/HIS.2014.7086191.

[8] Y. Yohannes, S. Devella, dan A. H. Pandrean. 2019, "Penerapan Speeded-Up Robust Feature pada Random Forest Untuk Klasifikasi Motif Songket Palembang,” JuTISI, Vol. 5, No. 3,

[9] S. Devella, Y. Yohannes, dan F. N. Rahmawati. 2020, "Implementasi Random Forest Untuk Klasifikasi Motif Songket Palembang Berdasarkan SIFT,” J. Tek. Inform. dan Sist. Inf., Vol. 7, No. 2, Hal. 310-320. 